\title{
Effects of Laying Cycle Periods on Egg Quality, Egg Chemical Composition, and Reproductive Performance of Japanese Quail Breeders Reared in Northern Algeria
}

\author{
Zahra Berrama $^{1,2 *}$,Samir Souames ${ }^{1,2}$, Rachid Merati ${ }^{2,3}$, Hakima Mefti Korteby ${ }^{4}$, Manel S. Chirane ${ }^{1}$, Nadia \\ Negab $^{1,5}$, Kenza Hettab ${ }^{1,5}$, Hayet Idris ${ }^{1,5}$, Nawel Morzouglal ${ }^{5}$, and Soraya Temim ${ }^{1,2}$ \\ ${ }^{1}$ Ecole Nationale Supérieure Vétérinaire, Alger, Algérie \\ ${ }^{2}$ Laboratoire de recherche Santé et Production Animale, ENSV, Algérie \\ ${ }^{3}$ Animal Hygiene and Pathology Laboratory, Ibn Khaldoun University, Tiaret, Algeria \\ ${ }^{4}$ Saad Dahlah University, Blida, Algeria \\ ${ }^{5}$ Department of Reproductive Biology and Physiology, USTHB, Algiers, Algeria \\ *Corresponding author's Email: z.berrama@ensv.dz; (D) ORCiD: 0000-0001-6422-3594
}

\begin{abstract}
Egg quality traits in quail breeders depend on various factors which may influence embryo survival during incubation, affecting the chicks' production and quality. The current study aimed to determine the effect of the laying period on the external and internal quality of the egg, the chemical composition of albumen, yolk, and eggshell as well as the reproductive parameters of quail breeders. A total of 450 quails (Coturnix japonica) obtained from the same hatchery, were reared in a battery cage with a sex ratio of 1 male to 3 females. All the quails were subjected to standard breeding conditions and fed a balanced laying diet. A total of 960 eggs were collected at two different periods of the laying cycle, the beginning period of the laying (BP indicating 10 weeks of quail age) and the peak period of laying (PP showing 20 weeks of quail age). At each laying period, 30 eggs were used to analyze the various parameters of egg quality, and 450 eggs were randomly selected to assess the reproductive performances. Overall, no differences in the external quality of eggs, such as egg length, egg width, and the egg shape index, were recorded between the two laying periods. Apart from albumen weight that tended to be higher at the peak laying period, the shell and the yolk weights were not affected by the period of laying. Additionally, Japanese quail tend to deposit similar proportions of shell, albumen, and yolk at the two periods of laying. Likewise, the rate of dry matter of the three egg components, shell mineral concentrations, and yolk fat concentrations did not show any noticeable variation with the laying period. The most significant effect of the laying period was related to the potential reduction in the total protein content of the albumen and the yolk of eggs laid at the peak period of laying. Finally, the laying period did not significantly affect the fertility and hatchability rate of the incubated quail eggs but slightly improved the embryonic mortality rate during the peak laying phase.
\end{abstract}

Keywords: Albumen, Coturnix japonica, Eggshell, Fertility, Quail

\section{INTRODUCTION}

To fight against food insecurity that increasingly threatens the growing world population, identifying alternative food resources is a key intervention to improve and ensure dietary protein. The integration of game birds, such as geese, guinea fowl, pheasant, and quail in FAO food security programs, has been recommended, especially for developing countries (Geldenhuys et al., 2013). As in several African countries, Algeria must be oriented towards the diversification of its animal protein resources due to its demographic growth, which may reach 74 million in 2050, and change consumers' eating habits, which is becoming more and more demanding. The development of quail farming could make it possible to improve the population's consumption of animal proteins (eggs and meat) at a lower cost (Kaci, 2015).

Hatching egg quality is a matter of great importance in the production of living and healthy chicks. Indeed, the physical and chemical properties of an egg play an essential role in the proper development of embryos by protecting them and ensuring their nutritional needs (Bai et al., 2016; D'Alba et al., 2016; Chen et al., 2019) and even serve as a food source during the first days of the chick's life (Abanikannda, 2007). However, as Zita et al. (2013) mentioned, several factors affect the reproductive performances and egg quality of Japanese quails. Some are directly linked to the animal (genetics, age of breeders, laying cycle), and others depend on the quails' rearing conditions, such as nutrition, rearing system, light, and temperature (Yambayamba and Chileshe, 2019, Ratriyanto et al., 2020), the sex ratio (Ipek et al., 2004) as well as the storage and incubation conditions of the eggs (Kuurman et al., 2002). 
The quail egg-laying period ranges from 8 to 12 months for breeders (Chelmonska et al., 2008) and could continue to 14 months for laying hens. This reproductive cycle is characterized by a beginning period of laying that lasts from the time when quails start laying (6 weeks) (Daikwo et al., 2014) to the time when quails lay maximum eggs, namely the peak laying period (17-22 weeks of age, Sauveur, 1988). The start of laying is a very critical period for female breeders. Their transfer from the grower house to the breeders' house could lead to stressful conditions for females, which results in poor laying start-up, and consequently low productivity and economic losses. Furthermore, it is well known that the weight of a bird determines its sexual maturity. Thereby, the variability of body weight within female breeders causes flock heterogeneity which may result in unsynchronized sexual maturity (delayed ovary development) and consequently failure in the mating process and performance.

Indeed, in the hen species, the beginning-laying phase of the breeders is characterized by high variability in egg quality, such as weight and egg fertility, most often attributed to the lack of uniformity of the flock (Pedroso et al., 2005).

The effects of breeder age were observed on the eggs' external and internal characteristics (Zita et al., 2013; Nasri et al., 2020), the eggs' fertility (Majhi et al., 2016), and embryonic development (Pokhrel et al., 2018). Several studies have revealed that during a laying period the weight of the eggs increases with the age of the breeders (Nasri et al., 2020). On the other hand, the weight and thickness of the shell decrease (Travel et al., 2010), and the proportion of yolk increases at the detriment of the albumen and shell proportions (Suarez et al., 1997). The beginning-laying period usually leads to the production of many small eggs. However, the component proportions of the hatching egg are affected by egg size. At the same breeders' age, smaller eggs contain more proportion of yolk than larger eggs (Vieira and Moran, 1998). It is well known that the egg yolk provides the nutrients for the developing embryo. However, the larger eggs, with a smaller proportion of yolk provide less nutrient content which could negatively affect embryo development and, consequently, incubation performance by increasing early and late embryo mortality. Moreover, the eggshell quality greatly influences the viability of the embryo and the hatchability of the eggs (Portugal et al., 2014; Ergun and Yamak, 2017).

Few studies have reported the effect of the laying period on Japanese quail reproductive parameters and quail egg quality so far. The objective of this study was to evaluate the effects of two laying periods of the breeders' quail, the beginning-laying period (BP) and the period of maximum production called the peak laying period (PP) on the external and internal quality of the hatching eggs as well as the variation of reproductive parameters.

\section{MATERIALS AND METHODS}

\section{Ethical approval}

The study was approved by the scientific council of the Superior National Veterinary School of Algeria with certificate reference 255/FDCS/2021.

\section{Quails (Coturnix japonica) and protocol design}

The current study was conducted at the farm of the technical institute of breeding, department of monogastric, Ministry of agriculture and rural development, BABA ALI, Algeria. A total of 960 eggs were obtained from 450 Japanese quail breeders, housed in a five-story battery cage. Each story was divided into 3 cages of 30 quails each, with a sex ratio of 3 females to 1 male. All the quails were subjected to the same standard breeding conditions and fed the same layer diet containing $2700 \mathrm{kcal.Kg}-1$ of metabolic energy, $19.01 \%$ of crude protein, $4 \%$ of calcium, and $0.7 \%$ phosphorous (ITELV, 1988).

All the eggs were collected at two different periods of the laying cycle, namely BP (at week 5 of egg production, representing 10 weeks of quail age) and PP (week 10 of egg production, representing 20 weeks of quail age). At each laying phase, 30 eggs were used to assess egg quality traits, and 450 eggs were randomly selected from eggs laid during one week to analyze the reproductive and hatching performances. For both laying phases (BP and PP), each egg was given individual identification and weighed by an electronic precision scale with $0.01 \mathrm{~g}$ accuracy. The length and width egg measurements were recorded by a caliper, and the egg shape index was calculated (SI $=$ width/length $\times 100$; Smai et al., 2018). At the end of the egg collection, the eggs for external and internal quality determination were transferred to a feed analysis laboratory of the Superior National Veterinary School. However, those used for reproductive traits assessment were set in a vertical incubator (La Nationale, France. Serial Number:4391) at a temperature of $37.7^{\circ} \mathrm{C}$, relative humidity of $60 \%$, and automatic egg-turning every 8 hours.

\section{Measurements of egg quality}

In the first step, each egg was broken. Afterward, eggshell, albumen, and yolk were carefully separated and weighed by a scale with $0.0001 \mathrm{~g}$ accuracy to determine their fresh weights and then expressed them as a percentage of whole egg weight (Zita et al., 2013). The dry matter (DM) of the three separated structures was determined by drying the 
samples at $80^{\circ} \mathrm{C}$ in a ventilated oven until constant weight ( 3 days). The chemical composition of each part of the quail egg was determined according to the methods of AOAC (1990), namely, eggshell mineral matter, yolk and albumin crude proteins, and yolk fat matter. Thus, the mineral matter of each dehydrated eggshell was determined by gradual incineration $\left(550^{\circ} \mathrm{C}\right)$ in a muffle furnace until all organic material was destroyed. The dry ash was weighed and then expressed as a DM percentage. The crude proteins of the albumen and yolk were determined using the Kjeldahl method by measuring the total nitrogen content and then using a factor of 6.25 to convert total nitrogen into crude proteins $(\mathrm{CP}=$ total nitrogen $\times 6.25$ ). The total fat of the yolk was determined by the Soxhlet method using petroleum ether as a solvent. The extraction process lasted for 18 hours. After completion of the extraction, the solvent was evaporated, and the mass of lipid remaining was dried in an oven, weighed, and then expressed as a DM percentage.

\section{Reproductive performances determination}

On day 14 of incubation, the eggs were removed from the incubator and candled to detect infertile eggs. On day 15 of incubation, the eggs were transferred to a hatcher where the temperature and relative humidity were maintained as $36.7^{\circ} \mathrm{C}$ and $80 \%$, respectively. After hatching, the unhatched eggs were broken to investigate fertility that was expressed as the fertile eggs/ incubated eggs $\times 100$. The hatchability of fertile eggs was determined as a number of chicks hatched/fertile eggs $\times 100$. The hatchability of incubated eggs was calculated as the number of chicks hatched /number of incubated eggs $\times 100$. Embryo mortality was obtained as the proportion of dead embryos out of the number of fertile eggs (Hegab and Hanafy, 2019).

\section{Statistical analysis}

Data were descriptively presented as means and subjected to one-factor variance analysis (ANOVA) performed with the Statview software (Abacus Concepts, 1996, Inc., Berkeley, CA94704-1014, USA). Version 4.57.0.0. StudentNewman-Keuls test was used to detect the differences. The statistical significance was set at $\mathrm{p} \leq 0.05$.

\section{RESULTS AND DISCUSSION}

\section{Egg external traits}

The external qualities of Japanese quail breeders' eggs laid at BP and PP are presented in Table 1. The results indicated that the laying period of Japanese quails did not affect the weight of the eggs $(\mathrm{p}>0.05)$. Also, no variation in the eggs' length, width, and shape index was associated with periods of the laying cycle ( $p>0.05)$. These findings are consistent with those obtained by some previous research (Moula et al., 2014; Smaï et al., 2018). In an experiment by Smaï et al. (2018), no difference in the egg weight of Japanese quails was observed between the two periods of laying (10.2 vs $11.1 \mathrm{~g}, \mathrm{p}>0.05$ at BP and PP, respectively). In contrast, other authors have reported different egg weights of Japanese quail in various phases of the reproductive cycle. Some studies revealed an increase in egg weight during the breeding cycle of Japanese quails (Nazligul et al., 2001). Zita et al. (2013) have reported that the egg weight increased in quails by $18 \%(\mathrm{p}<0.05)$ from the beginning phase of laying (week 9 of age) to the age of 21 representing the same peak laying phase in the current study. Moreover, it has been found that the egg shape index changes with the breeders' age (Molnar, 2016; Rakib et al., 2016; Kraus et al., 2020). In the present study, the shape index of eggs laid by the quail breeders remained unchanged on average over the two experimented periods of laying (77\% vs 76\% for BP vs PP, respectively). These results are consistent with those reported by Zita et al. (2013) and Moula et al. (2014) but did not agree with those of Orhan et al. (2001), who recorded a significant decrease in the form index of Japanese quail eggs by their age. Investigations in breeder hens and Peking ducks indicated a higher egg form index towards the end of the breeding season rather than the beginning (Romanoff and Romanoff, 1949; Kokoszynski et al., 2007). It is often acknowledged that at the beginning of production, the smaller eggs have a rather spherical shape, which tends to lengthen gradually during the laying period showing an ellipsoidal form for larger eggs (Gonzalez et al., 1982). This change in egg shape is thought to result from a weakening of the muscle tone of the shell gland in older hens (Travel et al., 2010).

Table 1. The effects of beginning and peak of laying periods on the external quality of eggs in Japanese breeder quails

\begin{tabular}{lccccc}
\hline \multirow{2}{*}{ Trait } & \multicolumn{2}{c}{ Laying Periods } & \multirow{2}{*}{ SEM } & \multirow{2}{*}{ p-value* } \\
\cline { 2 - 3 } & BP & PP & & 0.20 & 0.12 \\
Weight (g) & 10.72 & 11.18 & & 0.43 \\
Length (cm) & 2.95 & 2.98 & 0.03 & 0.02 & 0.89 \\
Width $(\mathrm{cm})$ & 2.28 & 2.28 & & 0.02 \\
Shape Index (\%) & 77.53 & 76.82 & 0.53 & 0.35 \\
\hline
\end{tabular}

BP: Beginning laying period, PP: Peak laying period. SEM: Standard Error of the Mean. *Significant differences ( $\mathrm{p} \leq 0.05)$. 


\section{Egg components}

The effects of the laying period (BP and PP) of Japanese breeder quails on the shell, albumen, and yolk weights, as well as their proportions in relation to the weight of whole quail eggs, are presented in Table 2.The laying periods (BP and PP) did not affect the weight of the different egg components, namely shell, albumen, and yolk ( $\mathrm{p}>0.05)$. Moreover, the current results have revealed that the proportions of the different quail egg components, such as eggshell, albumen, and yolk, do not change significantly with variations in the laying period ( $p>0.05)$. Eggs tended to have the same proportions of shell, albumen, and yolk at BP and PP periods. In contrast, Zita et al. (2010) recorded an increase in the weight of all three egg components over the variation in quail laying periods. Similarly, Moula et al. (2014) reported an impact of the laying period on the weights of the two nutritive components of the Japanese quail egg, namely albumen, and yolk. An increase of +3 and $+4 \%$ was recorded for quail eggs laid at 20 weeks of age for albumen and yolk, respectively. However, the same authors did not reveal any effect of the laying period on eggshell weight, whereas Curtis et al. (1986) reported that the percentage of shell in hens' eggs decreased throughout the production periods. During the laying period spanning from the beginning to the peak, albumen proportion increased from $61.10 \%$ to $62.10 \%$, however, the yolk proportion decreased from $30.97 \%$ to $29.75 \%$ during the same period (Nowaczewski et al., 2010). Hegab and Hanafy (2019) attribute this variation in weight and proportion of the different egg constituents with the laying period to the increase in weight, length, and width of the egg with the age of the breeders. Similarly, Cook et al. (2005) reported a tendency in yolk proportion to be lower in large eggs than smaller ones.

As the egg size increases, the relative amount of yolk decreases. Flock age and egg size are major factors that determine the albumen and yolk content in eggs (Nangsuay et al., 2011). Furthermore, Nasri et al. (2020) reported that as breeders become older, ovulation intervals increase. This results in equal quantities of yolk synthesized by the liver being deposited in fewer follicles causing higher yolk weights (Zakaria et al., 1983).

The effect of the laying period (BP and PP) of Japanese breeder quails on the shell, albumen, and yolk dry matter is presented in Figure 1. The effect of the laying period of Japanese breeder quails on mineral eggshell content, total protein albumen and yolk contents, and total yolk lipids is presented in Figure 2. No effect of laying period was noted for the rate of dry matter of the shell, the albumen, and the yolk of Japanese quail eggs ( $p>0.05)$. These results contrasted with the finding of Ulmer-Franco et al. (2009), who reported that dry shell percentage was greater in eggs laid by younger commercial broiler breeder hens than those laid by older hens. Similarly, Cook et al. (2005) and Nasri et al. (2020) found that whites from eggs produced by older hens had lower solids content than those obtained from younger hens. However, the latter authors showed that contrary to albumen DM, yolk DM percentage increased with breeder age.

The eggshell is the major source of minerals during the latter stages of embryonic development (Ono and Wakasugi, 1984; Solomon, 2010). Thus, this component should be considered when setting eggs for incubation to achieve successful hatching. In the current study, the laying period of Japanese quail breeders did not affect mineral deposition in the eggshell, the mineral matter percentage remained constant throughout the two periods of laying. These results are in agreement with the findings of Crosara et al. (2019), who reported that the contents of mineral eggshells are the same throughout the broiler breeders' life. Proteins are present primarily in egg albumen and egg yolk, while lipids are almost exclusively in the yolk (Nangsuay et al., 2011). In the present study, the crude protein concentrations in each of the albumen and yolk of quail eggs were influenced by the laying period. Both the yolk and albumen of eggs laid at the BP of laying contained $+28 \%$ and $+36 \%$ more crude proteins, respectively, than those of eggs laid at the PP of laying ( $\mathrm{p}<0.05)$. However, the laying period did not affect the concentration of the total lipid of the breeder quail egg yolk. Thus, a similar lipids deposition was recorded at the two periods of egg production. These results were consistent with those reported by Curtis et al. (1986), who noted a significant period effect on the percentage of albumen protein with a gradual decline over the production period and those that reported no effect of flock age on the lipids contents of hen egg yolk (Cook et al., 2005). In contrast, no variation in the yolk protein contents of eggs was observed to be associated with hens' ages (Cook et al., 2005).

Table 2. The effects of beginning and peak of laying periods on the shell, albumen and yolk weights, and their proportions in relation to the weight of whole eggs in Japanese breeder quails

\begin{tabular}{|c|c|c|c|c|c|}
\hline \multirow{2}{*}{ Egg components } & \multirow{2}{*}{ Trait } & \multicolumn{2}{|c|}{ Laying Periods } & \multirow{2}{*}{ SEM } & \multirow{2}{*}{$p$-value* } \\
\hline & & BP & $\mathbf{P P}$ & & \\
\hline \multirow{2}{*}{ Shell } & Weight $(\mathrm{g})$ & 5.33 & 5.74 & 0.16 & 0.07 \\
\hline & Weight proportion (\%) & 49.57 & 51.17 & 0.87 & 0.20 \\
\hline \multirow{2}{*}{ Albumen } & Weight (g) & 3.47 & 3.54 & 0.08 & 0.55 \\
\hline & Weight proportion (\%) & 32.39 & 31.60 & 0.48 & 0.26 \\
\hline \multirow{2}{*}{ Yolk } & Weight (g) & 1.52 & 1.58 & 0.15 & 0.75 \\
\hline & Weight proportion (\%) & 14.25 & 14.33 & 1.49 & 0.97 \\
\hline
\end{tabular}

BP: Beginning laying period, PP: Peak laying period. SEM: Standard Error of the Mean. * Significant differences $(\mathrm{p} \leq 0.05)$. 


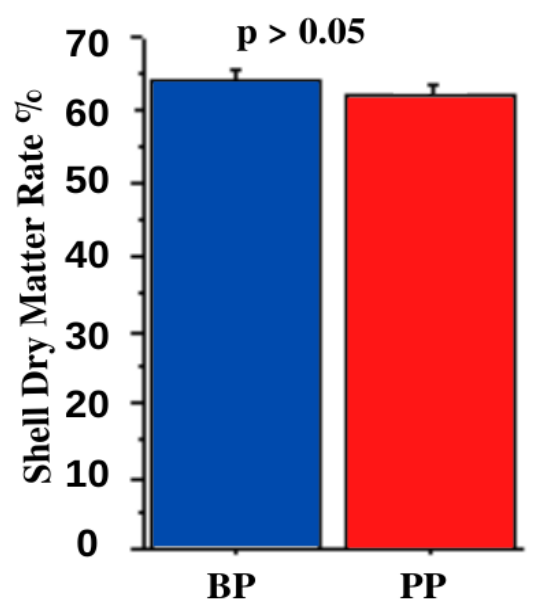

Laying Period

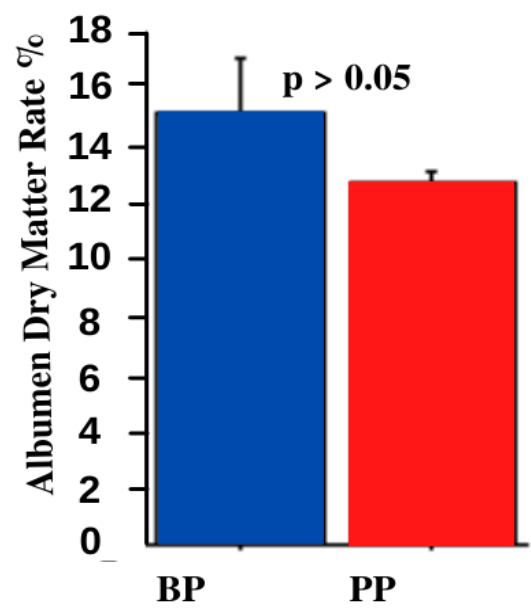

Laying Period

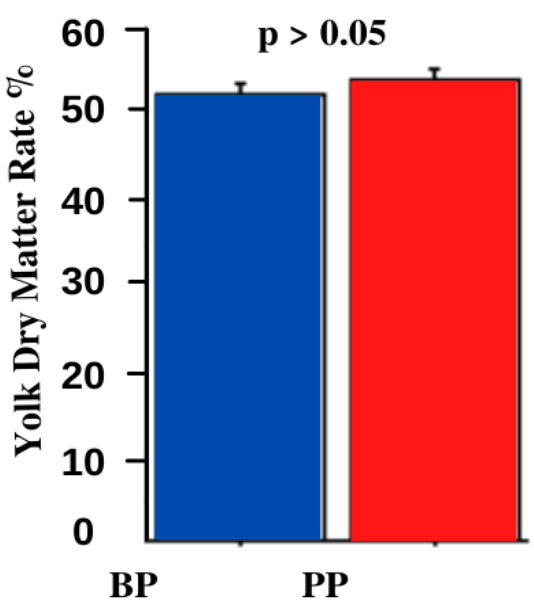

Laying Period

Figure 1.The effects of beginning and peak of laying periods on shell, albumen and yolk dry mater in Japanese quail breeders. BP: beginning laying period, PP: peak laying period, significant differences $(\mathrm{p} \leq 0.05)$.

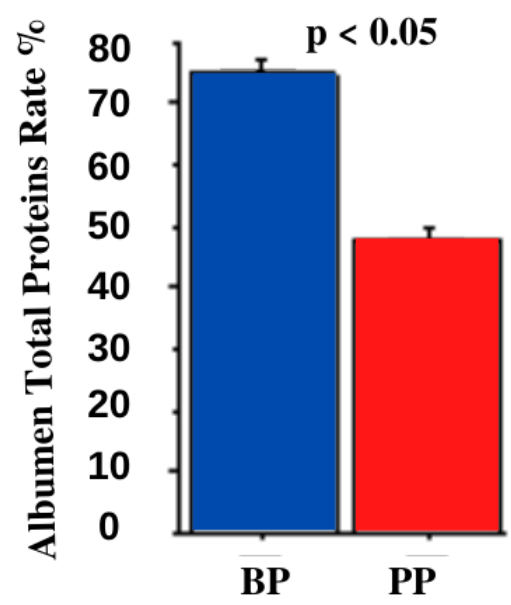

Laying Period

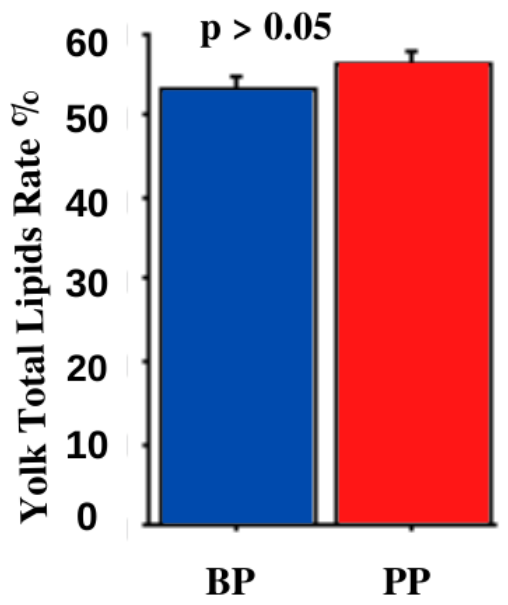

Laying Period

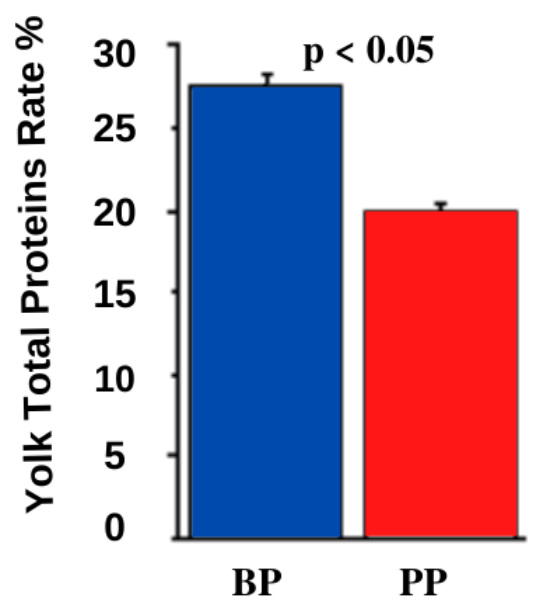

Laying Period

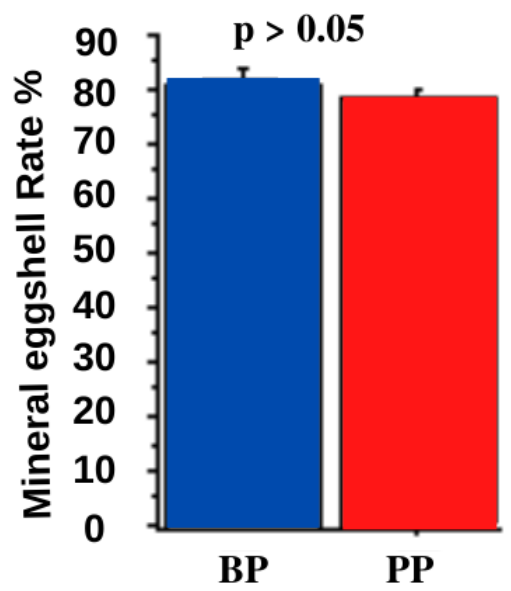

Laying Period

Figure 2. The effects of beginning and peak of laying periods on mineral eggshell content, total protein albumen and yolk contents and total yolk lipids in Japanese quail breeders. BP: beginning laying period, PP: peak laying period, significant differences ( $\mathrm{p} \leq 0.05$ ). 


\section{Reproduction parameters: Fertility, hatchability, and embryo mortality}

The effect of the laying period (BP and PP) of Japanese quail breeders on the fertility, hatchability, and embryo mortality of the incubated and fertile eggs is shown in Table 3. The current results indicated that the laying periods did not affect the fertility of the incubated eggs ( $p$ > 0.05). These results agreed with the findings of Ipek et al. (2004) regarding Japanese quail and those of Santos et al. (2015) concerning European quail. According to these authors, the laying period had no effect on egg fertility throughout the reproductive life of European quails. In contrast, Ipek et al. (2004) have shown that the fertility of eggs in Japanese quails was lower at ages of 7-10 weeks than those of 15-18 weeks. This inconsistency in results may be due to a difference in the experimental protocol, such as the applied malefemale ratio. In poultry, the male is one of the main factors limiting the fertility of flocks (Farooq et al., 2018). In fact, any delayed growth and sexual maturity in males affect sexual behaviors in young flocks, often caused by nutritional factors or inappropriate light stimulation (Brillard, 2003). Previous studies have explained the improvement of fertility rate at the peak of laying of quails by the acquiring of a greater number of mature ovarian follicles (Bagh et al., 2016). The laying period of the Japanese quail breeders did not significantly affect the hatchability of the incubated and fertile eggs $(p>0.05)$. However, statistical analysis revealed that the numerical values of hatchability rates tended to be slightly higher, with $+3.5 \%(\mathrm{p}=0.14)$ for incubated eggs and $+3 \%(\mathrm{p}=0.06)$ for fertile eggs during the peak laying period, compared to the beginning laying ones. Similarly, previous studies have reported that the laying period, which is closely related to the age of the breeders, has no effect on the hatching capacity of incubated eggs (Ipek et al., 2004; Smaï et al., 2018). Likewise, Smaï et al. (2018) did not detect any significant variation in the hatchability of incubated eggs during the breeding season of domestic quails. These authors recorded a numerical improvement in the hatching rate of the incubated eggs of $+7 \%(\mathrm{p}>0.05)$ between the period of the beginning of laying (8-12 weeks of age) and the period when the maximum eggs are laid (16th and 26th weeks of age). However, the recorded hatchability rate values remain lower (70\% vs. $75 \%$, respectively, BP and PP), compared to the results of the current study. These low rates could be explained by the sex ratio applied (1/2) by these researchers, which probably affected the fertility of the eggs and, consequently, their hatchability rate. Some contradictory findings were also reported. Elibol and Brake (2006) recorded better hatchability of incubated eggs in laying hens at the early-laying period, compared to the other periods of the reproductive cycle. Seker et al. (2004) reported a higher hatchability rate of fertile eggs at the peak of laying (93.33\%) than at the beginning of laying $(81.53 \%)$. The variation in the hatching rate of fertile eggs during a reproductive cycle is most often attributed to a variation in the quality of the eggs during that cycle (Sahan et al., 2014; Boleli et al., 2016). In the current study, the laying period did not affect the embryo mortality rate of the incubated eggs ( $>0.05$ ). A similar result was reported by Santos et al. (2015) in European quail. However, a significant decrease of $-40 \%$ in the mortality rate for the fertile eggs during the PP of laying is recorded $(\mathrm{p}=0.05)$.

However, Majhi et al. (2016) and Amiar et al. (2017) noted a gradual decrease in embryo mortality of incubated eggs from the beginning to the peak period of laying. In the same trend, Seker et al. (2004) recorded an improvement in the embryonic mortality rates of fertile eggs over the two periods of the reproductive cycle. This is in contrast with Wilson et al. (2003), who suggested an opposite effect of quail age on embryonic mortality due to the poor positioning of the embryos before hatching. It should be noted that in poultry, several physiological parameters change with flock age (O'Sullivan et al 1992). The most noticeable change is the increasing egg weight (North and Bell, 1991). Indeed, Hegab and Hanafy (2019) reported that the embryonic mortality rate is lower for heavy eggs, compared to lighter eggs, which is explained by the richness of heavy eggs in sufficient nutrient reserves, compared to lighter eggs.

Table 3. The effects of beginning and peak of laying periods on the fertility, hatchability, and embryo mortality of the incubated and fertile eggs in Japanese breeder quails

\begin{tabular}{|c|c|c|c|c|c|}
\hline \multirow{2}{*}{ Trait } & \multirow{2}{*}{ Parameters } & \multicolumn{2}{|c|}{ Laying Periods } & \multirow{2}{*}{ SEM } & \multirow{2}{*}{$p$-value } \\
\hline & & BP & $\mathbf{P P}$ & & \\
\hline Fertility (\%) & Incubated egg & 95.11 & 94.89 & 1.03 & 0.88 \\
\hline \multirow{2}{*}{ Hatchability (\%) } & Incubated egg & 86.89 & 90.00 & 1.50 & 0.14 \\
\hline & Fertile egg & 91.36 & 94.61 & 1.22 & 0.06 \\
\hline \multirow{2}{*}{ Mortality (\%) } & Incubated egg & 12.67 & 9.33 & 1.47 & 0.11 \\
\hline & Fertile egg & 8.18 & 4.92 & 1.18 & 0.05 \\
\hline
\end{tabular}

BP: Beginning laying period, PP: Peak laying period. SEM: Standard Error of the Mean. *Significant differences $(\mathrm{p} \leq 0.05)$.

\section{CONCLUSION}

In conclusion, the laying period shows stability in egg external quality, their overall composition, and in the most of chemical components of albumen, yolk, and shell. Nevertheless, the peak of laying has a large negative impact on the protein rate of albumen and yolk but without affecting the threshold egg quality needed for the successful development 
of the embryo. Eggs laid by quail breeders at the beginning and the peak periods of laying were of equal fertility and hatchability performances. However, the low proteins could affect negatively chicks' quality at hatch and their growth performances. Further research must be conducted to draw more clear conclusions, determining the effect of quality of eggs on growth performances of chicks hatched from eggs of different periods of laying cycle and examining the possible interaction effects of the laying period with other factors such as egg storage duration.

\section{DECLARATIONS}

\section{Authors' contribution}

Z Berrama and H Mefti-Korteby designed the experiment, Z Berrama, S Souames, and R Merati curated the data. Laboratory analyses were done by MS Chirane, N Negab, H Idris, K Hettab, and Z berrama. Z Berrama wrote the manuscript. S Temim, S Souames, and N Morzouglal revised the manuscript. All authors confirmed the manuscript's final draft and data analysis.

\section{Competing interests}

The authors have not declared any conflict of interest.

\section{Ethical consideration}

Ethical issues (including plagiarism, consent to publish, misconduct, data fabrication and/or falsification, double publication and/or submission, and redundancy) have been checked by all the authors.

\section{REFERENCES}

Abanikannda OTF, Olutogun O, Leigh AO and Ajayi LA (2007). Statistical modelling of egg weight and egg dimension in commercial layers. International Journal of Poultry Science, 6: 59-63. DOI:https://www.doi.org/10.3923/ijps.2007.59.63

Amiar WH (2017). Study of the effect of the use of a quail-type feed on the reproduction performance of the Japanese quail Coturnica japonica. Agronomic Master thesis pp.1-38. University of Abdelhamid Ibn Badis Mostaganem. Available at: http://e-biblio.univmosta.dz/handle/123456789/12401

AOAC (1990). Official methods of analysis of the Association of Official Analytical Chemists. 15th Edition, Arlington, VA, (USA) pp. 1028-1039. Available at:https://law.resource.org/pub/us/cfr/ibr/002/aoac.methods.1.1990.pdf

Bagh J, Panigrahi B, Panda N, Pradhan CR, Mallik BK, Majhi B and Rout SS (2016). Body weight, egg production, and egg quality traits of gray, brown, and white varieties of Japanese quail (Coturnix coturnix japonica) in coastal climatic condition of Odisha. Veterinary World, 9: 832-836. DOI: https://www.doi.org/10.14202/vetworld.2016.832-836

Bai JY, Pang YZ, Zhang X and Li YX (2016).Study on the morphological development of quail embryos. Revista Brasileira de Ciência Avícola, 18: 91-93. DOI: https://doi.org/10.1590/1806-9061-2015-0177

Boleli IC, Morita VS, Matos JJB, Thimotheo M and Almeida VR (2016). Poultry Egg Incubation: Integrating and Optimizing Production Efficiency. Brazilian Journal of Poultry Science, 18(2): 1-16. DOI: https://www.doi.org/10.1590/1806-9061-2016$\underline{0292}$

Brillard JP (2003). Practical aspects of fertility in poultry. World's Poultry Science Journal, 59: 441-446. DOI: https://doi.org/10.1079/WPS20030027

Chelmonska B, Jerysz A , Lukaszewicz E, Kowalczyk A and Malecki I (2008).Semen collection from Japanese quail using a teaser female. Turkish Journal Veterinary and Animal Science, 32: 19-24. Available at: https://journals.tubitak.gov.tr/veterinary/issue.htm?id=757

Chen X, Li X, He Z, Hou Z, Xu G, Yang N and Zheng J (2019).Comparative study of eggshell antibacterial effectivity in precocial and altricial birds using Escherichia coli, PLoS ONE, 14(7): e0220054. DOI: https://www.doi.org/10.1371/journal.pone.0220054

Cook MI, Beissinger SR,Toranzos GA and Arendt WJ (2005).Incubation reduces microbial growth on eggshells and the opportunity for trans-eggshell infection. Ecology Letter, 8: 532-537. DOI: https://www.doi.org/10.1111/j.1461-0248.2005.00748.x.

Crosara FSG, Pereira VJ, Lellis CG, Barra KC, Santos SKA, Souza LCGM, Morais TA, Litz FH, Limao VA, Braga PFS and Fernandes EA (2019). Is the Eggshell Quality Influenced by the Egg Weight or the Breeder Age? Brazilian Journal of Poultry, 21: 1-8. DOI: http://www.dx.doi.org/10.1590/1806-9061-2018-0896

Curtis PA, Gardner F A and Mellor D B (1986). A comparison of selected quality and compositional characteristics of brown and white shell eggs. III. Composition and nutritional characteristics. Poultry Science, 65: 501-507. DOI: https://www.doi.org/10.3382/ps.0650501

Daikwo SI, Dim NI and Momoh MO (2014). Genetic parameters of some Egg Production traits in Japanese quail in a tropical Environment. OSR-JAVS. 7: 39-42. DOI: https://www.doi.org/10.9790/2380-07933942

D'Alba L, Maia R, Hauber ME and Shawkey MD (2016). The evolution of eggshell cuticle in relation to nesting ecology. Proceedings Royal Society B, 283:2832016068720160687 DOI: https://wwwdoi.org/10.1098/rspb.2016.0687

Elibol O and Brake J (2006). Effect of flock age, cessation of egg, and turning frequency through the second week of incubation on hatchability of broiler hatching eggs. Poultry Science, 85: 1498-1501. DOI: https://www.doi.org/10.1093/ps/85.8.1498.

Ergun OF and Yamak US (2017). The effect of eggshell thickness on hatchability of quail eggs. Veterinary World, 10:1114-1117. DOI: https://www.doi.org/10.14202/vetworld.2017.1114-1117 
Farooq U, Malecki IA, Misbah M and Graeme BM (2018). Correlation between objective semen analysis and fertility in Japanese quail.Theriogenology, 4: 12. DOI: https://www.doi.org/10.1016/j.theriogenology.2018.04.012

Geldenhuys G, Hoffman LC and Muller N (2013). Aspects of the nutritional value of cooked Egyptian goose (Alopochen aegyptiacus) meat compared with other well-known fowl species. Poultry Science, 92: 3050-3059. DOI: https://www.doi.org/10.3382/ps.2013-03342

Gonzalez M, Roca P, Sainz F and Alemany M (1982). A comparison between egg surface areas and volumes of several avian species. Comparative Biochemistry and Physiology Part D, 73: 301-302. DOI: https://doi.org/10.1016/0300-9629(82)90074-3

Hegab IM and Hanafy AM (2019). Effect of Egg Weight on External and Internal Qualities, Physiological and Hatching Success of Japanese Quail Eggs (Coturnix coturnix japonica). Brazilian Journal of Poultry Science, 21: 1-8. DOI: https://www.doi.org/10.1590/1806-9061-2018-0777

Institut Technique des Elevages (ITELV) (1988). Guide d'élevage de la caille et du pigeon. Institut Technique des Elevage, BABA ALI, ALGERIA pp. 28. Available at: http://www.itelv.dz/index.php/telechargements/send/54-aviculture/237-guide-d-elevage-dela-caille-et-du-pigeon-itpe-1988.html

Ipek A, Sahan U and Yilmaz B (2004). The effect of live weight, male to female ratio and breeder age on reproduction performance in Japanese quails (Coturnix coturnix japonica). South African Journal of Animal Science, 34: 130-134. Available at: https://www.sasas.co.za/journals/the-effect-of-live-weight-male-to-female-ratio-and-breeder-age-on-reproduction-performancein-japanese-quails-coturnix-coturni/

Kaci A (2015). La filière avicole algérienne à l'ère de la libéralisation économique. Cahiers Agricultures, 24: 151-160. DOI: https://www.doi.org/10.1684/agr.2015.0751

Kokoszynski D, Bernacki Z and Korytkowska H (2007). Eggshell and egg content traits in peking duck eggs from the P44 reserve flock raised in Poland. Journal Central European. Agriculture, 8: 9-16. DOI: https://jcea.agr.hr/en/issues/article/398

Kraus A, Zita L, Krunt O, Volek Z, Tyller M and Anderle V (2020). Comparison of basic internal and external egg quality traits of brown and white egg-laying hens in relationship to their age. Acta Universitatis Agriculturae et Silviculturae Mendelianae Brunensis, 68: 49-56. DOI: https://www.doi.org/10.11118/actaun202068010049

Kuurman WW, Bailey BA, Koops WJ and Grossman M (2002). Influence of storage days on the distribution for time of embryonic mortality during incubation. Poultry Science, 81: 1-8. DOI: https://www.doi.org/10.1093/ps/81.1.1

Majhi B, Panigrahi B, Panda N, Mallik BK, Pradhan CR, Bagh J and Chichilichi B (2016). Effect of age and mating ratio on fertility and hatchability of Japanese quail (Coturnix coturnix japonica) in the coastal climate of Odisha. Indian Journal of Poultry Science, 51: 187-91. DOI: https://www.doi.org/10.5958/0974-8180.2016.00030.1

Molnar A, Maertens L, Ampe B, Buys J, Kempen I, Zoons J and Delezie E (2016). Changes in egg quality traits during the last phase of production: is there potential for an extended laying cycle? British Poultry Science, 57(6): 842-847. DOI: https://www.doi.org/10.1080/00071668.2016.1209738

Moula N, Philippe FX, Ait Kaki A, Touazi L, Antoine-Moussiaux N and Leroy P (2014). Ponte et qualité d'œufs de cailles élevées en conditions semi intensives dans l'est algérien. Archivos de Zootecnia, 63: 693-966. DOI: http://www.dx.doi.org/10.4321/S0004$\underline{05922014000400013}$

Nangsuay A, Ruangpanit Y, Meijerhof R and Attamankune S (2011). Yolk absorption and embryo development of small and large eggs originating from young and old breeder hens. Poultry Science, 90: 2648-2655. DOI: https://www.doi.org/10.3382/ps.2011$\underline{01415}$

Nasri H, Van Den Brand H, Najjar T and Bouzouaia M (2020). Egg storage and breeder age impact on egg quality and embryo development. Journal of Animal physiology and animal nutrition, 104: 254-68. DOI: https://www.doi.org/10.1111/jpn.13240

Nazligul A, Turkyilmaz K and Bardakcioglu HE (2001). A study on some production traits and egg quality characteristics of Japanese quail. Turkish Journal Veterinary and Animal Science, 25: 1007-1013. Available at https://journals.tubitak.gov.tr/veterinary/abstract.htm?id=5119

North MO and Bell DD (1991). Commercial chicken production manual. 4th ed. Van Nostrand Reinhold, pp.710. Available at: https://scholar.google.com/scholar_lookup?title=Commercial\%20Chicken\%20Production\%20Manual\&publication_year=1990\& author=M.O.\%20North\&author=D.B.\%20Bell

Nowaczewski S, Kontecka H, Rosiński A, Koberling S and Koronowski P (2010) Egg quality of Japanese quail depends on layer age and storage time. Folia Biologica (Krakow), 58: 201-207. DOI: https://www.doi.org/10.3409/fb58_3-4.201-207.

O’Sullivan NP, Dunningtone A and Siegel PB (1991). Relationships Among Age of Dam, Egg Components, Embryo Lipid Transfer, and Hatchability of Broiler Breeder Eggs. Poultry Science, 70: 2180-2185. DOI: https://www.doi.org/10.3382/ps.0702180

Ono T and Wakasugi N (1984). Mineral content of quail embryos cultured in mineral-rich and mineral-free conditions. Poultry Science, 63: 159-166. DOI: https://www.doi.org/10.3382/ps.0630159.

Orhan H, Erensaying C and Aktan S (2001). Determining egg quality characteristics of japanese quails (Coturnix Coturnix Japonica) at different ages. Journal of Animal Production, 42: 44-49. Available at: https://dergipark.org.tr/en/download/article-file/85202

Pedroso AA, Andrade MA, Café MB, Leandro NS, Menten JF and Stringhini JH (2005). Fertility and hatchability of eggs laid in the pullet-to-breeder transition period and in the initial production period. Animal Reproduction Science, 90: 355-364. DOI: https://www.doi.org/10.1016/j.anireprosci.2005.03.001

Pokhrel N, Ben-Tal Cohen E, Genin O, Ruzal M, Sela-Donenfeld D and Cinnamon YE (2018). Effects of storage conditions on hatchability, embryonic survival and cytoarchitectural properties in broiler from young and old flocks. Poultry Science, 97: 14291440. DOI: https://www.doi.org/10.3382/ps/pex393

Portugal SJ, Maurer G, Thomas GH, Hauber ME, Grim T and Cassey P (2014). Nesting behaviour influences species-specific gas exchange across avian eggshells. Journal of Experimental Biology, 217: 3326-3332. DOI: https://www.doi.org/10.1242/jeb.103291 
Rakib TM, Akter L, Barua SR, Nur EA, Erfan R, Islam MS Faruk AA, Faruk M, and Miazi OF (2016). Effects of age, rearing system and their interaction on phenotypic characteristics in hisex brown laying hens. Scientific Journal of Veterinary Advances, 5: 8796. DOI: $\underline{\text { https://www.doi.org/10.14196/SJVA.V5I5.2174 }}$

Ratriyanto A, Firmand F, Purwanti H, and Murjoko M (2020). Nutrient digestibility, performance, and egg quality traits of quails raised in different stocking densities and ascorbic acid supplementation in a hot, tropical environment. Turkish Journal Veterinary and Animal Science Sci(2020) 44: 350-357. DOI:https://www.doi.org/10.3906/vet-1909-1

Romanoff AL and Romanoff AJ (1949). The Avian Egg. Ed. John Wiley \& Sons, (NY), (USA) pp.918. Available at: https://www.cabdirect.org/cabdirect/abstract/19490101699

Şahan U, Ipek A and Sozcu A (2014). Yolk sac fatty acid composition, yolk absorption, embryo development, and chick quality during incubation in eggs from young and old broiler breeders. Poultry Science, 93: 2069-2077. DOI: https://www.doi.org/10.3382/ps.2013-03850.

Santos TC, Murakami AE, Oliveira CAL, Moraes GV, Stefanello C, Carneiro TV, Feitosa CCG and Kaneko IN (2015). Influence of European Quail Breeders Age on Egg Quality, Incubation, Fertility and Progeny Performance. Brazilian Journal of Poultry Science, 17: 49-56. DOI: https://www.doi.org/10.1590/1516-635x170149-56

Sauveur B (1988). Reproduction des volailles et production d'œufs. $1^{\text {ère }}$ édition. (Inra) Paris pp.472. Available at: https://hal.inrae.fr/hal-02858486

Seker I, Kul S and Bayraktar M (2004). Effects of parental age and hatchability egg weight of japanese quails on hatchability and chick weight. International Journal Poultry Scencei, 3: 259-265. DOI: https://www.doi.org/10.3923/ijps.2004.259.265

Smaï A, Saadi-Idouhar H, Zenia S, Haddadj F, Ameziane S, Koulougli S, Milla A, Marniche F and Doumandji S (2018). Effects of the age of breeding females on the characteristics of the eggs of japanese quails in Algeria. Livestock Research for Rural Development,30: Article ID: 145. Available at: http://www.lrrd.org/lrrd30/8/amina30145.html

Solomon SE (2010). The eggshell: strength, structure and function. British Poultry Science; 51: 52-59. DOI: https://doi.org/10.1080/00071668.2010.497296

Suarez ME, Wilson HR, Mather FB, Wilcox CJ, and Mcpherson BN (1997). Effect of strain and age of the broiler breeder female on incubation time and chick weight Poultry Science, 76: 1029-1036. DOI: https://www.doi.org/10.1093/ps/76.7.1029.

Travel A, Nys Y and Lopes E (2010). Facteurs physiologiques et environnementaux influençant la production et la qualité de l'œuf. INRA Production Animal, 23: 155-166. DOI: https://www.doi.org/10.20870/productions-animales

Ulmer-Franco AM, Fasenko GM and O'Dea Christopher EE (2010). Hatching egg characteristics, chick quality, and broiler performance at 2 breeder flock ages and from 3 egg weights. Poultry Science, 89: 2735-2742. DOI: https://www.doi.org/10.3382/ps.2009-00403

Vieira SL and Moran Jr (1998). Eggs and chicks from broiler breeders of extremely different age. Journal of Applied Poultry Research, 7: 392-402. DOI: https://www.doi.org/10.1093/japr/7.4.372

Wilson HR, Neuman SL, Eldred AR and Mather FB (2003). Embryonic Malpositions in Broiler Chickens and Bobwhite Quail. Journal of Applied Poultry Research, 12: 14-23. DOI: https://www.doi.org/10.1093/japr/12.1.14

Yambayamba KES, and Chileshe PC (2019). Effect of Increased Photoperiod on Feed Intake, Egg Production and Egg Size in Japanese Quail (Coturnix japonica) Under Zambian Conditions. EC Veterinary Science, 4: 334-342. Available at: https://www.ecronicon.com/ecve/pdf/ECVE-04-00109.pdf

Zakaria AH, Miyaki T and Imai K (1983). The effect of aging on the ovarian follicular growth in laying hens. Poultry Science, 62: 670-674. DOI: https://www.doi.org/10.3382/ps.0620670

Zita L, Ledvinka Z and Klesalova L (2013). The effect of the age of Japanese quails on certain egg quality traits and their relationships. Veterinarski Arhiv, 83: 223-232. Available at: https://core.ac.uk/download/pdf/14463833.pdf 